BOOK REVIEW

\section{Cutting-edge bioethics: a Christian exploration of technologies and trends}

Edited by J F Kilner, C C Hook, D B Uustal. Eerdmans, 2002, £5.99/\$22.00, pp xii-201. ISBN 0802849598

In an age where developments in biotechnology offer new possibilities for overcoming disease at a breathtaking rate, there is a certain timeliness in recalling C S Lewis's farsighted depiction of "the magician's bargain", "that process whereby man surrenders object after object, and finally himself, to nature in return for power". ${ }^{1}$ Lewis's reflections on the implications of science's quest for mastery over nature, outlined in his renowned essay The Abolition of Man, highlight the coercive tendencies of this yearning for control. In practice, he argues, "power over nature turns out to be a power exercised by some men over other men with nature as its instrument", and ironically proves not to be a power that humanity can wield for its chosen ends, but rather one that enslaves its pursuers to their appetite for domination (Lewis, ${ }^{1}$ p 35 and the discussion which follows). In seeking, through technical control, to transcend our bodily limits (limits signified in part by the burden of disease) we embrace a technocratic mindset that, if adopted unconditionally, will lead us to regard our given identity as raw material to be "improved" by mechanical means.

This collection of essays aims to give fresh voice to this warning in the face of the very latest in biotechnological innovations. In the words of the editors, it is intended as a "wake up call," informing readers of the exciting possibilities for health care in the future, and equipping them with the concepts with which to appraise them from a Christian perspective. Like C S Lewis, the contributors are keen to dispel any suggestion that their guarded tone betrays an aversion to exploring new technological possibilities in medicine. Indeed, endorsement of the considerable benefits promised by emerging technologies is a recurrent motif throughout the book Rather, the cause of their disquiet is doubt as to whether the cultural environment fostering these developments has the moral wherewithal to ensure they are put to legitimate use. Allied, so it would seem, with the secularisation of society, is the growing spectre of "transhumanism,"-movement promoting the belief "that humanity is something to be overcome and replaced by our technologies" (page $\mathrm{x}$ ). Although the numbers prepared explicitly to endorse this creed might be few at the moment, the writers envisage that the allure of recent technological developments seeming to offer freedom from the frustrations of ill health could tempt an increasing number to adopt attitudes in which transhumanist assumptions take a more covert form. In the light of this threat, the book makes a commendable appeal for a proactive approach to ethical analysis, one that anticipates forthcoming developments by observing present trends, so that appropriate precautions can be taken well in advance of those developments becoming a reality.

Cutting-edge bioethics consists of 15 papers from a broad range of experts from various relevant disciplines, including scientists, ethicists, and theologians. The content is similarly broad in scope, with some articles exploring the science and ethics of particular technologies and developments in the management of health care, and others reflecting on more conceptual issues, such as "multiculturalism" and "the need for bioethical vision".

On the whole, these essays are accessible and informative, offering illuminating accounts of the scientific and ethical aspects of their subjects, and provoking the sort of emotional reaction one might associate with a "wake up call". As might be expected in a compilation of such variety, some essays made more compelling reading than others. The opening paper by Francis Collins on "Human genetics" was one of the ones I found more disappointing. Given the cautionary note sounded in the introduction about the potential destructiveness of emerging technologies, it was surprising to read in Collins's opening section his "bottom line", that "the promise of this research is so great for medicine that the most unethical thing we can do is to slow it down" (page 3).

In a book that is forthright about its desire to be a Christian assessment of biotechnology, I would have thought it more fitting to affirm as fundamental that the most unethical course of action was one that contradicted God's will and created order. It is far from obvious that this is synonymous with slowing the progress of biomedical research! Although in fairness, Collins does point out the importance of attending to social, ethical, and legal issues, the bulk of his attention is given over to extolling the virtues of the Human Genome Project. On the occasions where theological matters get a mention, they tend to be simplistic and selectively presented to endorse this positive account of genetic research. That being said, Collins's explanation of the Human Genome Project is instructive, and his closing section on "Ethical challenges ahead" highlights a number of significant areas for further reflection.

Subsequent papers in this opening section, entitled "Emerging technologies", achieved a better balance of scientific description and theological reflection. Included are papers on xenotransplantation, transgenics, artificial intelligence, cybernetics, and nanotechnology. All are comprehensive and thoughtful discussions of some of the very latest innovations whose applications, in some cases, have largely still to be realised.

The next section of the book explores the context in which these technologies are arising, identifying and analysing prevalent cultural characteristics in essays on multiculturalism and our increasing enthusiasm for more sophisticated technological interventions. The first of these offers an incisive philosophical critique of the widespread assumption that a relativistic "all cultures are equal" approach to ethics is essential in contemporary society. Daryl Sas's paper, "Reliance on technology: stem cell research and beyond", tended to be oversimplistic, with bold assertions that, lacking more careful substantiation, seemed rather presump- tuous-for example, his passing reference to "eternal judgement for tampering with or destroying human embryos" (page 85). Nonetheless its basic assertion that technology needs to be adopted responsibly and ordered to God's creative intentions is well said. It was, however, the final essay in this section, Francis Cardinal George's on "The need for bioethical vision", which was, in my view, the jewel of the trio.

Although avowedly Catholic in his outlook, George offers insights to which Christians of all denomination should pay careful attention. These include a lucid discussion of Christian anthropology, specifically the relationship between natural and resurrected bodily life, which should form the basis of any Christian witness in the biomedical sphere.

From matters of technology and context, the focus shifts to recent developments in health care management. The American context from which the book emerges is particularly evident in Scott Rae's essay on "Money matters in health care", with its focus on the recent transition in US health care delivery from a "fee for service" to a "managed care" system. For readers less au fait with health policy in America, more background explanation would have been helpful. Nonetheless, there is some incisive discussion of the interface between business priorities and medical care. Other articles in the section deal with "Spirituality and alternative medicine" (with the focus on studies exploring the role of intercessory prayer in healing), "Preventing AIDS and STDs", and "The ethic and spirit of care" (a broader discussion of the nature of care and its corresponding responsibilities in a therapeutic context).

The final section of the book concentrates on the need for proactive engagement affirmed at the outset. Since astute anticipation is a vital ingredient in this process, Richard Swenson's essay proposes guidelines for predicting forthcoming developments, and offers some of his own expectations of health care characteristics in the future. Occasionally these predictions seem to lack the realism Swenson insists is essential for making accurate predictions-for example "Successful human cloning is a certainty, most likely within the decade" (page 171), but remains thorough in its coverage of future possibilities. Helen Alvare offers some practical tips on making constructive use of the media to "speak out" for a Christian vision of health care in the public arena. A final essay by Ben Mitchell explores some key questions about the nature and responsibilities of being human that need conscientious attention as this "biotech century" unfolds.

As a whole, this is a helpful and engaging collection of essays. Although there are moments when a more robust theological critique would have been beneficial, the breadth and accessibility of the book conveys should aid readers of all sorts in the "search for wisdom" that its editors hope to encourage.

M Peat michael.peat@regents-park.oxford.ac.uk

\section{References}

1 Lewis CS. The abolition of man. London: Fount Paperbacks, 1978. 